\title{
Characterisation of a type IV pilus produced by Aeromonas caviae
}

\author{
S. M. KIROV, K. SANDERSON and T. C. DICKSON \\ Division of Pathology, University of Tasmania, Hobart, Tasmania 7001, Australia
}

\begin{abstract}
A pilus produced by a clinical isolate of Aeromanas caviae (strain CA195) was purified and partially characterised. The $M_{r}$ of the pilin was estimated to be $23 \mathrm{kDa}$ by SDSPAGE. Its N-terminal amino-acid sequence showed that it was closely related to 'bundleforming' type IV pili purified from other Aeromonas spp. associated with gastro-enteritis and considered to be important intestinal colonisation factors. Bundle-forming pili, often with a polar location, were seen on the surface of strain CA195 which was highly adherent to HEp-2 cells. Removal of surface structures by mechanical means decreased adhesion (by $\geqslant 50 \%$ ) suggesting that these pili played some role in HEp-2 cell binding. This pilus type could prove an important marker for enteropathogenic $A$. caviae which appear to lack other putative virulence factors.
\end{abstract}

\section{Introduction}

Aeromonas caviae is one of the three Aeromonas spp. most frequently associated with gastro-enteritis, particularly in paediatric patients and travellers [1-3]. Despite this, its enteropathogenicity has been controversial. Strains of $A$. caviae reportedly lack virulence factors found in diarrhoea-associated $A$. hydrophila and $A$. veronii biovar sobria $[4,5]$, although it has been postulated that exotoxins may be produced under different assay conditions to those found optimal for these other Aeromonas spp. [6,7].

Adhesion to the intestinal mucosa is likely to be a major determinant of pathogenicity. There are several reports that diarrhoea-associated isolates of $A$. caviae are highly adherent to human cell lines used as intestinal cell models [8-10]. Filamentous structures have been implicated, but adherence-related extracellular appendages have not yet been isolated or characterised from A. caviae $[10,11]$. This study examined diarrhoeaassociated isolates of $A$. caviae from Australian patients for putative virulence-associated properties that might help delineate enteropathogenicity.

\section{Materials and methods}

\section{Bacterial strains}

Twenty-two clinical isolates of $A$. caviae, isolated in Queensland in 1993 (Mr M. Tandy, Sullivan, Nico-

Received 20 Oct. 1997; accepted 2 Dec. 1997.

Corresponding author: Dr S. M. Kirov. laides and Partners, Private Pathology, Taringa, Queensland, Australia) were included in this study. Twenty isolates were from faeces of patients with severe or persistent diarrhoea. Eight of the patients with diarrhoeal symptoms were infants $\leqslant 2$ years old, two were $\geqslant 55$ years old, four were aged between 2 and 55 years, and details of patient age were not available for the remaining six patients. All isolates had the $A$. caviae phenotype [12]. The strain from which pili were purified (strain CA195) was isolated from a 1-year-old male infant with severe diarrhoea. Its speciation (hybridisation group 4) was also confirmed by genetic typing (rRNA gene restriction patterns) by $\mathrm{Dr} \mathrm{M}$. Altwegg, University of Zürich, Switzerland [13]. Shortterm storage of isolates was in minimal maintenance medium at room temperature [14]; long-term storage was in glycerol-peptone ( $1: 4$ glycerol: bacteriological peptone $1 \%$, Oxoid L 37 ) at $-80^{\circ} \mathrm{C}$.

\section{Exotoxin assays}

Full details of these assays are given elsewhere $[14,15]$. Briefly, bacteria were cultured $\left(37^{\circ} \mathrm{C}, 24 \mathrm{~h}\right.$ with shaking) in tryptone soya broth supplemented with yeast extract L21 (Oxoid $6 \mathrm{~g} / \mathrm{L}$ ) (TSBY). Bacteria-free broth supernates from these cultures were assessed for haemolytic activity against rabbit red blood cells, enterotoxic activity in suckling mice and cytotoxic activity for Vero cells. Supernates from bacteria grown under different culture conditions, including double strength trypticase soya broth with no glucose $(2 \times$ TSBGlu-) [16] and iron limitation (TSBY containing deferoxamine mesylate $100 \mu \mathrm{g} / \mathrm{ml}$ ) [17], were also tested in these assays. 


\section{Adhesion assay}

Isolates $\left(1 \times 10^{6} \mathrm{cfu}\right)$ were examined for their ability to adhere to HEp-2 cells after growth in TSBY at $22^{\circ} \mathrm{C}$ for $48 \mathrm{~h}$ [18]. Each isolate was assessed on triplicate coverslip cultures of semi-confluent HEp-2 cells on two or more occasions. Strains with a mean number of 510 bacteria/cell were defined as 'adherent', those with $\geqslant 10$ bacteria/cell as 'highly adherent'.

\section{Electron microscopy}

Bacterial cells and purified pili preparations were absorbed on to formvar-coated copper grids and negatively stained (uranyl acetate $1 \%, 30 \mathrm{~s}$ ). They were examined with a Philips 410 electron microscope [19].

\section{Purification of pili}

Bacteria were grown in static TSBY cultures at room temperature $\left(\sim 20^{\circ} \mathrm{C}\right)$ for 2 days. They were harvested from $5 \times 1-\mathrm{L}$ cultures, resuspended in $100 \mathrm{ml}$ of $0.05 \mathrm{M}$ Tris- $\mathrm{HCl}(\mathrm{pH} \mathrm{7.4)}$ and chilled on ice. They were stirred with a magnetic stirrer (Magnestir, LabLine Instruments, Melrose Park, IL, speed 4.5) for $2 \mathrm{~h}$ $\left(4^{\circ} \mathrm{C}\right)$ to remove loosely associated material. Bacteria recovered by centrifugation $(2000 \mathrm{~g}, 30 \mathrm{~min})$ were resuspended in $60 \mathrm{ml}$ of $0.05 \mathrm{M}$ Tris- $\mathrm{HCl}$. Pili were removed from the bacterial cell surface with an Omnimixer (Omni International, Waterbury, CT, USA) at speed 3-4 for $10 \mathrm{~s}$ at 10 -s intervals with intermittent cooling for $2 \mathrm{~min}$. After centrifugation $(26000 \mathrm{~g}$, $30 \mathrm{~min}$ ), the supernate was filtered through a $0.2-\mu \mathrm{m}$ pore membrane (Gelman Sciences). Proteins in the final supernate were precipitated with polyethylene glycol 6000 (PEG; Rhône-Polenc, Manchester) 1\% and $\mathrm{NaCl} 5.8 \%$ and held at $4{ }^{\circ} \mathrm{C}$ overnight. Precipitated proteins were collected by centrifugation $(26000 \mathrm{~g}$, $30 \mathrm{~min}$ ) and resuspended in $0.05 \mathrm{M}$ Tris buffer. The precipitation procedure and foregoing cycle was repeated on the resulting supernate with PEG $2 \%$ and then $6 \%$. The 1,2 and $6 \%$ protein precipitates were examined by electron microscopy and SDS-PAGE. Pili in the PEG $2 \%$ precipitate were further purified by suspending the precipitate in $10 \mathrm{ml}$ of $0.05 \mathrm{M}$ Tris- $\mathrm{HCl}$ and repeating the cycle of $P E G$ precipitation described above.

\section{SDS-PAGE analysis of crude pili preparations}

SDS-PAGE was performed as described by Laemmli [20] in a discontinuous acrylamide $15 \%$ gel (MiniPROTEAN II, BioRad, USA).

\section{$N$-terminal amino-acid sequence analysis}

Proteins were transferred from SDS-PAGE gels to polyvinylidene difluoride (PVDF) membrane (MiniTransblot cell, BioRad) and visualised with amido black $(1 \% \mathrm{w} / \mathrm{v}$ in methanol $40 \% \mathrm{v} / \mathrm{v}$, acetic acid $1 \%$ $\mathrm{v} / \mathrm{v})$. They were sequenced by automated Edman degradation employing a Porton P12090 equipped with 'on-line' PTH-amino-acid analysis (Macquarie University Centre for Analytical Biotechnology, Sydney, Australia).

\section{Results}

Toxin production and adhesion by $A$. caviae isolates

While broth supernates from a control strain of $A$. veronii biovar sobria grown under standard conditions had haemolytic titres $\geqslant 1024$, were strongly cytotoxic for Vero cells and elicited positive suckling mouse responses, supernates from all $22 \mathrm{~A}$. caviae isolates were negative for haemolysin and enterotoxin and four only were weakly cytotoxic for Vero cells. Toxic activities did not increase when $A$. caviae strains were grown in $2 \times$ TSBGlu-, or under iron-limitation, for 20-24 h. However, 55\% (12 of 22) of the isolates were adherent to HEp-2 cells, seven isolates being highly adherent. Adherent strains showed diffuse binding (uniform distribution over the cell surface) (Fig. 1).

\section{Surface structures on adherent clinical strains of A. caviae}

Electron microscopy of adherent strains showed that the $A$. caviae isolates were generally poorly piliate (growth in TSBY, $22^{\circ} \mathrm{C}, 48 \mathrm{~h}$ ), with only a few (usually $<10$ ) long, wavy pili present on each bacterial cell. Growth of selected environmental and clinical strains at low temperature $\left(4^{\circ} \mathrm{C}\right)$ did not increase pili expression as was found for many strains of $A$. veronii biovar sobria [19]. Bundle-forming pili were seen after culture at $22^{\circ} \mathrm{C}$ on a small proportion $(5-10 \%)$ of the bacterial population of one highly adherent clinical isolate (strain CA195) (Fig. 2A, B and C). These bundleforming pili (Bfp) often had a polar location and were sometimes seen closely associated with the flagellum (Fig. 2B and C). Removal of pili from this strain by mechanical blending (Omni-mixer, speed 3-4 for

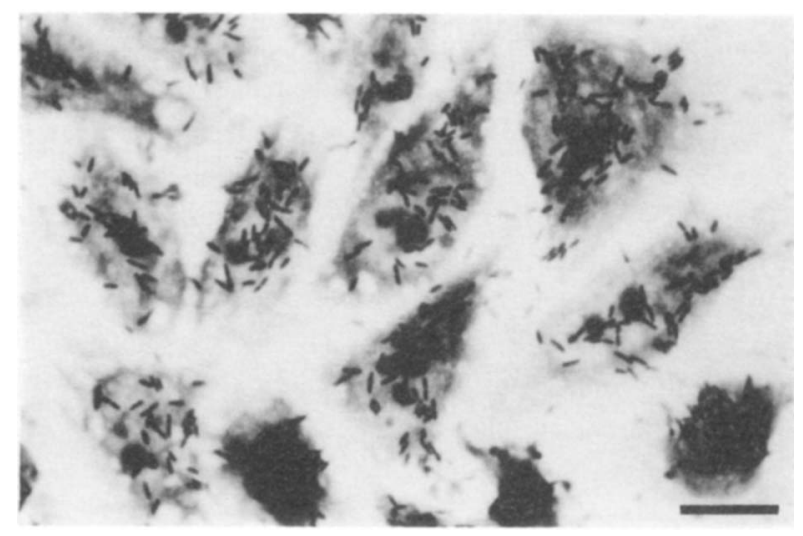

Fig. 1. Adhesion of A. caviae to HEp-2 cells. A. caviae strains grown in tryptone soya broth containing yeast extract $0.6 \%$ at $22^{\circ} \mathrm{C}$ for $48 \mathrm{~h}$ had a diffuse adherence pattern characterised by a uniform distribution of bacteria over the cell surface. Bar, $12 \mu \mathrm{m}$. 

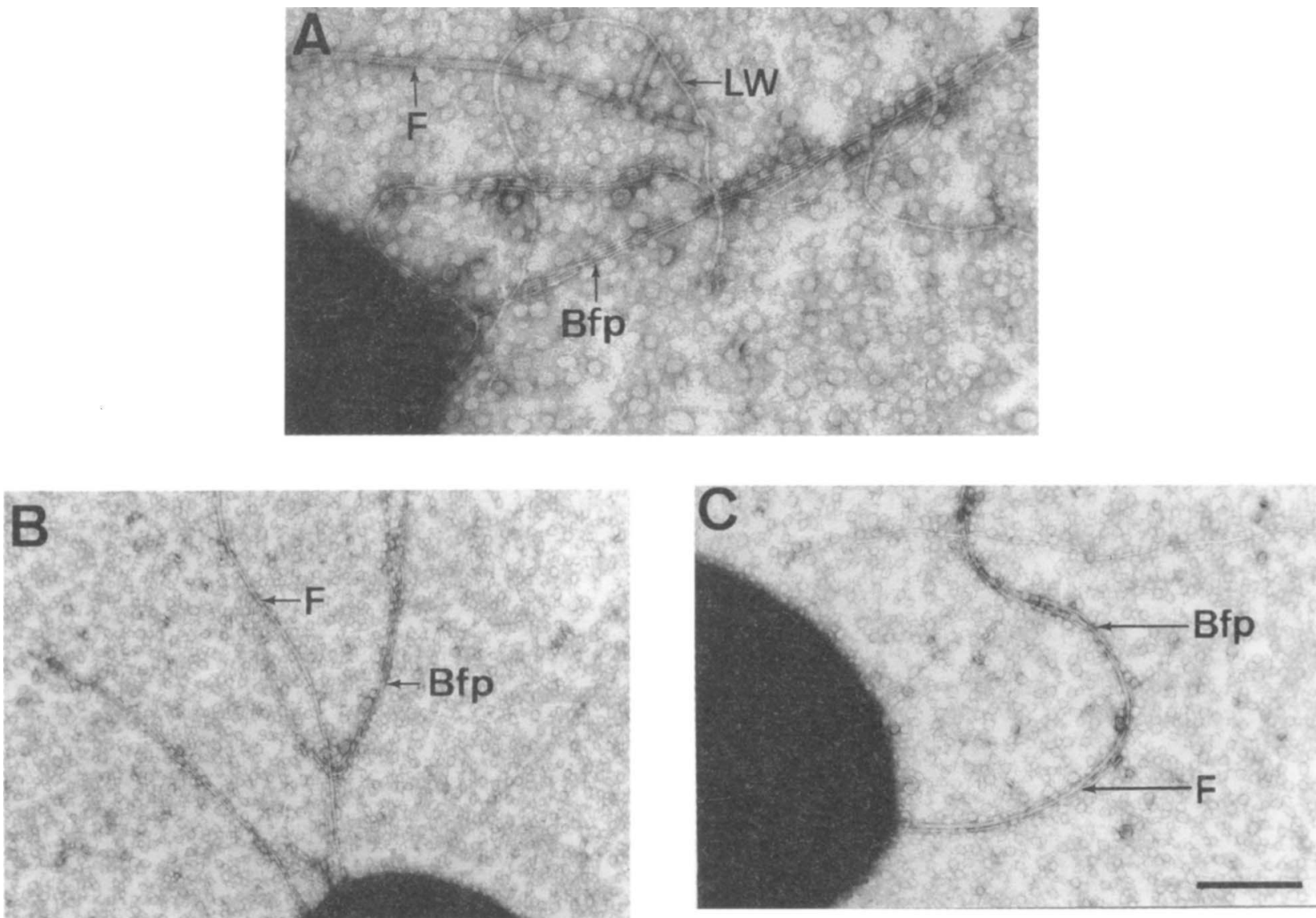

Fig. 2. Transmission electron micrographs showing negatively stained, filamentous surface structures of $A$. caviae strain CA195 after culture in tryptone soya broth containing yeast extract $0.6 \%$ at $22^{\circ} \mathrm{C}$ for $48 \mathrm{~h}$. (A) Shows flagellum (F), an isolated long, wavy pilus (LW) and bundles of long, thin, flexible pili (Bfp). Bfp were seen on a small proportion (5$10 \%$ ) of bacteria of some adherent strains. Bar, $1.6 \mu \mathrm{m}$. (B) and (C) The long, flexible, bundle-forming pili of strain CA195 tended to have a polar location and were often seen closely associated with the single polar flagellum $(\mathrm{F})$. Bars, $3.3 \mu \mathrm{m}$ and $2.6 \mu \mathrm{m}$.

5 min) decreased adhesion to HEp- 2 cells by $>50 \%$. Therefore, experiments were done to purify and characterise the pili of this $A$. caviae isolate.

\section{Purification and characterisation of filamentous surface structures of strain CA195}

Pili from A. caviae strain CA195 proved more difficult to purify than the pili of an $A$. veronii biovar sobria strain (strain BC88) previously studied [21]. Unlike the latter strain, with which a discrete pilin subunit band was readily identified on SDS-PAGE analysis, preparations from the $A$. caviae strain resulted in multiple ( $>15$ ) protein bands, with several bands in the $M_{r}$ region of type IV pilins $(17-25 \mathrm{kDa})$. Modifications of the blending procedure (shorter blending time, reduced speed) did not markedly affect this protein band pattern. Electron microscopy of the PEG 1\%, 2\% and $6 \%$ precipitated fractions of the pili blendates revealed that the greatest concentration of flexible pili was in the $2 \%$ fraction. Therefore, this was re-precipitated with PEG $1 \%$ and $2 \%$. Bundles of pili and isolated pili as well as some contaminating flagella fragments were seen in the latter preparation (Fig. 3). Two putative pilin subunit bands (c. $19 \mathrm{kDa}$ and $23 \mathrm{kDa}$ ) were obtained on SDS-PAGE analysis of this preparation. These were readily seen on silver-stained gels, but both bands stained poorly with Coomassie Brilliant Blue. However, the 23-kDa band was the predominant protein recovered.

\section{$N$-terminal amino-acid sequencing and relationship to other purified Aeromonas pilins}

$\mathrm{N}$-terminal analysis of this $23-\mathrm{kDa}$ protein was determined on two occasions with two different pili preparations. Unambiguous sequences (13 and 30 amino acids, respectively) were obtained. These showed that the $23-\mathrm{kDa}$ protein was type IV pilin (Fig. 4). Fig. 4 also compares the A. caviae pilin sequence with the sequences of other Aeromonas type IV pili purified to date. These clearly form a related family of pilins which we have collectively named 'bundle-forming pili' (Bfp) because of their tendency to form bundles on the bacterial surface [21]. Bfp have been shown to be intestinal colonisation factors for Aeromonas species [22-26]. The N-terminal sequence of the purified A. caviae pilin was identical to that of a 


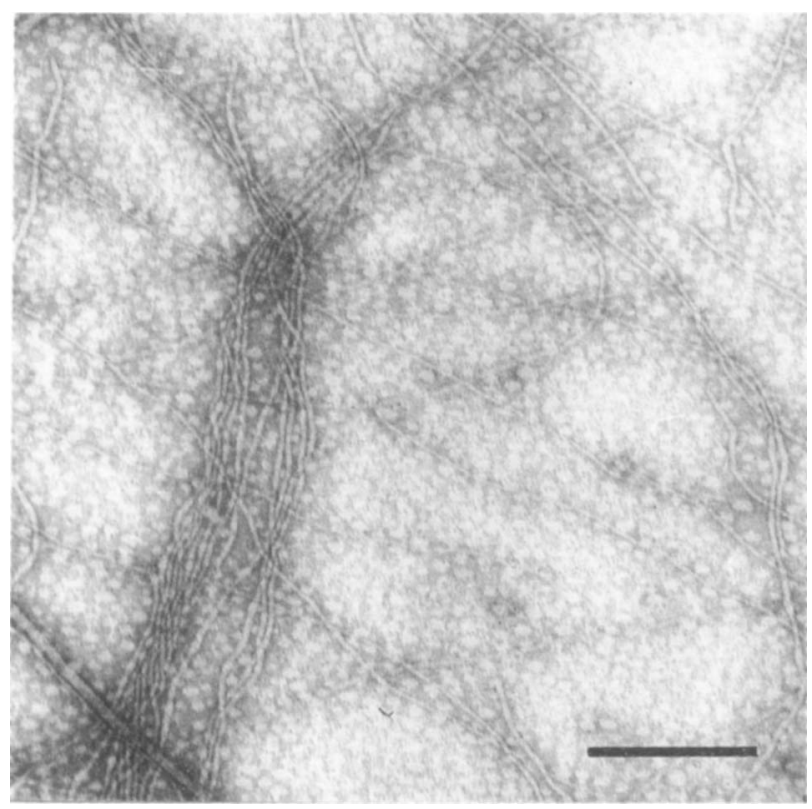

Fig. 3. Electron micrograph of negatively stained purified A. caviae CA195 pili. The preparation contains some contaminating flagella (F). Bar, $0.25 \mu \mathrm{m}$.

Bfp isolated earlier from $A$. veronii biovar sobria (strain BC88). However, the two pili are antigenically distinct, as antiserum to the $A$. veronii biovar sobria Bfp did not react with the $A$. caviae pilus. The reported variability in the first amino acid of the Bfp pilins is most likely a reflection of altered migration patterns on HPLC columns of a modified penultimate amino acid which makes definitive identification of this amino acid difficult.

Sequences derived from two recently cloned Aeromonas type IV pilin genes are also shown in Fig. 4 $[27,28]$. The cloned pilins, designated 'type IV Áeromonas pili' (Tap), form a second family of Aeromonas type IV pilins with related N-terminal sequences that differ significantly from those of the
Bfp pilins. Tap pili do not appear to be assembled under the standard bacterial growth conditions [28]. A recent study reported that strain CA195 possesses the Tap gene cluster [28].

\section{Discussion}

For A. caviae to be a gastrointestinal tract pathogen it must be able to colonise the intestinal mucosa. This study has confirmed reports from other geographical regions that clinical strains of $A$. caviae are able to adhere to epithelial cell lines used as models for intestinal cell binding $[1,8-10]$. Moreover, this is the first study to show that highly adherent $A$. caviae possess type IV pili of the family shown to be intestinal colonisation factors for strains of $A$. veronii biovar sobria and A. hydrophila [22-25].

Because of high background antibody titres to $A$. caviae proteins, this study was unable to produce a polyclonal antiserum in rabbits which would definitively link the purified $23-\mathrm{kDa}$ type IV pilin to the pili seen on the $A$. caviae surface. However, it was the predominant protein band on SDS-PAGE analysis of purified pili preparations and by analogy with an earlier study on the related pilin from a strain of $A$. veronii biovar sobria we postulate that most pili expressed (including the pili bundles) were composed of it. It is possible that the $19-\mathrm{kDa}$ band observed in purified pili preparations was a second pilin type, but insufficient protein was obtained for sequencing. Long, wavy pili of varying widths $(4-6 \mathrm{~nm}$ and $7-9 \mathrm{~nm}$ ) were observed occasionally on individual bacteria and in purified preparations (Figs. 2 and 3). The strain from which the $23-\mathrm{kDa} \mathrm{Bfp}$ was purified possesses the Tap gene cluster, so it has the potential to produce this second family of type IV pilin also, although in none of the pili purification studies to date has this pilin type been isolated, despite the widespread occurrence of the gene [28].

Purified pilins (Bfp)

Reference

A. caviae (CA195)

A. veronii biovar sobria (BC88)

A. sobria (Ae24)

A. sobria (TAP13)

A. sobria (Ae1)

A. hydrophila (Ae6)

A. trota (1220)

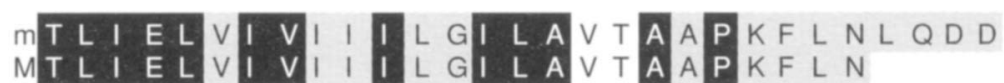

$M T L I E L V I V I I I L G I L A V T A A P K F L N$ [21]

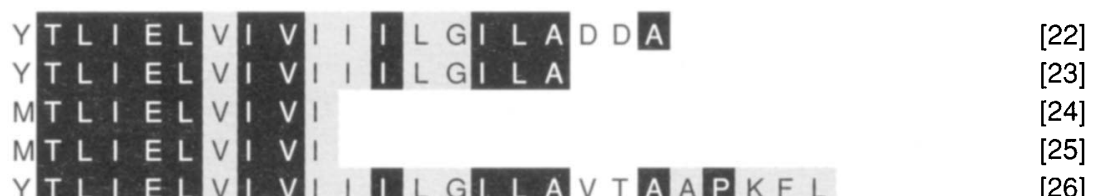

[26]

\section{Cloned pilins (Tap)}

A. hydrophila (Ah65)

A. veronii biovar sobria (BC88)
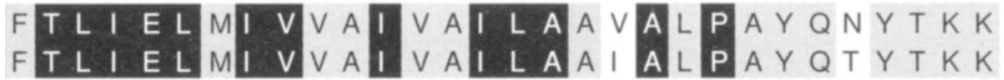

Fig. 4. The N-terminal amino acid sequence of the purified $23-\mathrm{kDa}$ pilin of $A$. caviae strain CA195 compared with the published sequences of other Aeromonas pilins. 
Eley et al. reported seeing different types of filamentous appendages on $A$. caviae strains and postulated that patterns of cell line adhesion seen after various bacterial growth conditions reflected the expression of different adhesins [11]. They observed that HEp-2 adhesion patterns varied from localised to aggregative in the first phase of exponential growth to a persisting diffuse adherence after the start of stationary phase. Under the assay conditions chosen for the present experiments $A$. caviae strains showed a diffuse adhesive pattern and adhesion to HEp-2 cells was only in part mediated by filamentous structures. Merino et al. suggested that lipopolysaccharide is another important adhesin for Aeromonas strains binding to HEp-2 cells [29].

The Australian $A$. caviae strains showed little evidence of toxin production either under standard assay conditions or when grown under conditions reported to favour production of toxins by $A$. caviae isolates in the USA [16,17]. The mechanism(s) by which adherent $A$. caviae may bring about diarrhoeal disease, therefore, remain in doubt. However, this study has identified a pilus marker for strains that are likely to be significant in vivo.

This work was supported by a grant from the Australian National Health and Medical Research Council (NHMRC). We thank Mrs I. Jacobs for her assistance with the electron microscopy.

\section{References}

1. Namdari H, Bottone EJ. Aeromonas caviae: ecologic adaptation in the intestinal tract of infants coupled to adherence and enterotoxin production as factors in enteropathogenicity. Experientia 1991; 47: 434-436.

2. Rautelin H, Hänninen ML, Sivonen A, Turunen U, Valtonen V. Chronic diarrhea due to a single strain of Aeromonas caviae. Eur J Clin Microbiol Infect Dis 1995; 14: 51-53.

3. Wilcox MH, Cook AH, Eley A, Spencer RC. Aeromonas spp. as a potential cause of diarrhoea in children. $J$ Clin Pathol 1992; 45: 959-963.

4. Barer MR, Millership SE, Tabaqchali S. Relationship of toxin production to species in the genus Aeromonas. $J \mathrm{Med}$ Microbiol 1986; 22: 303-309.

5. Gracey M, Burke V, Robinson J. Aeromonas-associated gastroenteritis. Lancet 1982; 2: 1304-1306.

6. Karunakaran T, Devi BG. Characterisation of haemolytic activity from Aeromonas caviae. Epidemiol Infect 1994; 112: $291-298$.

7. Namdari H, Bottone EJ. Microbiologic and clinical evidence supporting the role of Aeromonas caviae as a pediatric enteric pathogen. J Clin Microbiol 1990; 28: 837-840.

8. Grey PA, Kirov SM. Adherence to HEp-2 cells and enteropathogenic potential of Aeromonas spp. Epidemiol Infect 1993; 110: 279-287.

9. Neves MS, Nunes MP, Milhomem AM. Aeromonas species exhibit aggregative adherence to HEp-2 cells. J Clin Microbiol 1994; 32: 1130-1131.

10. Thornley JP, Shaw JG, Gryllos IA, Eley A. Adherence of Aeromonas caviae to human cell lines Hep-2 and Caco-2. $J$ Med Microbiol 1996; 45: 445-451.

11. Eley A, Shaw JG, Thornley JP, Geary I. Isolation and initia identification of adherence-related extracellular appendages in Aeromonas caviae. Med Microbiol Lett 1995; 5: 40-45.

12. Carnahan AM, Behram S, Joseph SW. Aerokey II: a flexible key for identifying clinical Aeromonas species. $J$ Clin Microbiol 1991; 29: 2843-2849.

13. Martinetti Lucchini G, Altwegg M. rRNA gene restriction patterns as taxonomic tools for the genus Aeromonas. Int $J$ Syst Bacteriol 1992; 42: 384-389.

14. Kirov SM, Rees B, Wellock RC, Goldsmid JM, Van Galen AD. Virulence characteristics of Aeromonas spp. in relation to source and biotype. J Clin Microbiol 1986; 24: 827-834.

15. Kirov SM, Hui DS, Hayward LJ. Milk as a potential source of Aeromonas gastrointestinal infection. J Food Protect 1993; 56: $306-312$.

16. Namdari H, Bottone EJ. Cytotoxin and enterotoxin production as factors delineating enteropathogenicity of Aeromonas caviae. $J$ Clin Microbiol 1990; 28: 1796-1798.

17. Ho ASY, Mietzner TA, Smith AJ, Schoolnik GK. The pili of Aeromonas hydrophila: identification of an environmentally regulated "mini pilin". J Exp Med 1990; 172: 795-806.

18. Kirov SM, Hayward LJ, Nerrie MA. Adhesion of Aeromonas $\mathrm{sp}$. to cell lines used as models for intestinal adhesion. Epidemiol Infect 1995; 115: 465-473.

19. Kirov SM, Jacobs I, Hayward LJ, Hapin RH. Electron microscopic examination of factors influencing the expression of filamentous surface structures on clinical and environmental isolates of Aeromonas veronii biotype sobria. Microbiol Immunol 1995; 39: 329-338.

20. Laemmli UK. Cleavage of structural proteins during the assembly of the head of bacteriophage T4. Nature 1970; 227: $680-685$.

21. Kirov SM, Sanderson K. Characterization of a type IV bundleforming pilus (SFP) from a gastroenteritis strain of Aeromonas veronii biovar sobria. Microb Pathog 1996; 21: 23-34.

22. Hokama A, Iwanaga M. Purification and characterization of Aeromonas sobria Ae24 pili: a possible new colonization factor. Microb Pathog 1992; 13: 325-334.

23. Iwanaga M, Hokama A. Characterization of Aeromonas sobria TAP13 pili: a possible new colonization factor. $J$ Gen Microbiol 1992; 138: 1913-1919.

24. Hokama A, Iwanaga M. Purification and characterization of Aeromonas sobria pili, a possible colonization factor. Infect Immun 1991; 9: 3478-3483.

25. Hokama A, Honma Y, Nakasone N. Pili of an Aeromonas hydrophila strain as a possible colonization factor. Microbiol Immunol 1990; 34: 901-915.

26. Nakasone $\mathrm{N}$, Iwanaga $\mathrm{M}$, Yamashiro $\mathrm{T}$, Nakashima $\mathrm{K}$, Albert MJ. Aeromonas trota strains, which agglutinate Vibrio cholerae O139 Bengal antiserum, possess a serologically distinct fimbrial colonization factor. Microbiology 1996; 142: 309-313.

27. Pepe CM, Eklund MW, Strom MS. Cloning of an Aeromonas hydrophila type IV pilus biogenesis gene cluster: complementation of pilus assembly functions and characterization of a type IV leader peptidase/N-methyltransferase required for extracellular protein secretion. Mol Microbiol 1996; 19: $857-869$.

28. Barnett TC, Kirov SM, Strom MS, Sanderson K. 1997. Aeromonas spp. possess at least two distinct type IV pilus families. Microb Pathog 23: 241-247.

29. Merino S, Rubires X, Aguilar A, Tomás JM. The O:34-antigen lipopolysaccharide as an adhesin in Aeromonas hydrophila. FEMS Microbiol Lett 1996; 139: 97-101. 